\title{
Morphological and molecular identification with frequency analysis of Calicophoron microbothrioides in central Chile
}

\author{
Identificação morfológica e molecular com análise de frequência de Calicophoron microbothrioides na \\ região central do Chile \\ Carolina Cerda ${ }^{1}$; Joseline Veloso-Frías ${ }^{1}$; Felipe Lobos-Chávez'; Pablo Oyarzún-Ruiz ${ }^{1}$ (i); AnaLía Henríquez²; \\ Marco Loyola ${ }^{2}$; María Carolina Silva-de la Fuente ${ }^{1,2}$; René Ortega ${ }^{1}$; Reinaldo Letelier ${ }^{1}$; Carlos Landaeta-Aqueveque ${ }^{1 *}$ (1) \\ ${ }^{1}$ Facultad de Ciencias Veterinarias, Universidad de Concepción, Chillán, Chile \\ ${ }^{2}$ Facultad de Medicina Veterinaria, Universidad San Sebastián, Concepción, Chile
}

Received May 08, 2019

Accepted August 22, 2019

\begin{abstract}
This research aimed to determine the presence of paramphistomids in cattle slaughtered in a slaughterhouse of the Nuble Region of Chile, to identify flukes and to analyze the frequency of these parasites in the Maule, Nuble, and Biobío administrative regions of Chile. Between October of 2016 and April of 2017, rumens of 494 cattle were examined for flukes in the forestomachs. Worms were identified morphologically and, in addition, molecular analysis of the internal transcriber spacer region 2 of the fluke's DNA was done and phylogenetic analyses were performed with Bayesian inference in 14 worms. The frequency was analyzed by locality (low- or highlands) and age. The overall frequency was $11.24 \%$. The district with the highest frequency of presentation was Chillán Viejo (30.8\%). Districts in the lowlands had similar frequencies to those in the mountain lands $(p=0.1)$. The frequency of flukes was significantly higher in adult animals than in young ones $(p<0.01)$. We obtained a $460 \mathrm{bp}$-length fragment of DNA that was identical to the sequences previously identified as Paramphistomum cervi and Calicophoron microbothrioides, and performed morphological analyses confirmed that our samples belonged to C. microbothrioides. This is the first published study of C. microbothrioides in Chile.
\end{abstract}

Keywords: Paramphistomidae, ruminal flukes, bovine, epidemiology, ITS-2, Calicophoron microbothrioides.

\section{Resumo}

Este trabalho teve como objetivo determinar a presença de paramphistomídeos em bovinos abatidos em um matadouro da Regiáo do Nuble do Chile, para identificar parasitas e analisar a frequência desses parasitos nas regiôes administrativas de Maule, Nuble e Biobío, no Chile. Entre outubro de 2016 e abril de 2017, rúmens de 494 bovinos foram examinados à procura de vermes no pré-estômago. Os vermes foram identificados morfologicamente e, além disso, a análise molecular da regiáo interna do espaçador do transcritor 2 do DNA e análises filogenéticas foram realizadas com inferência bayesiana em 14 vermes. A frequência foi analisada pela altitude da localidade (baixa ou alta) e idade. A frequência geral foi de $11,24 \%$. O distrito com as maiores frequências de parasitismo foi Chillán Viejo (30,8\%). Os distritos das terras baixas tinham frequências semelhantes às encontradas nas terras das montanhas $(p=0,17)$. A frequência foi significativamente maior em animais adultos do que em jovens $(p<0.01)$. Obtivemos um fragmento de DNA de $460 \mathrm{pb}$ que era idêntico às sequências anteriores identificadas como Paramphistomum cervi e Calicophoron microbothrioides, e realizamos análises morfológicas que permitiram confirmar que nossas amostras pertenciam a C. microbothrioides. Este é o primeiro estudo publicado sobre C. microbothrioides no Chile.

Palavras-chave: Paramphistomidae, vermes ruminais, bovino, epidemiologia, ITS-2, Calicophoron microbothrioides.

\section{Introduction}

Paramphistomids are ruminal trematodes with a worldwide distribution, they affect both domestic and wild ruminant (SANABRIA et al., 2011; HUSON et al., 2017; ALI et al., 2018; NARANJO-LUCENA et al., 2018; O'CONNOR et al., 2018).

*Corresponding author: Carlos Landaeta-Aqueveque. Facultad de Ciencias Veterinarias, Universidad de Concepción, Vicente Méndez, 595, Chillán, Chile.e-mail: clandaeta@udec.cl
The impact of this parasitosis is variable; some regions have reported it as a very pathogenic disease (DORNY et al., 2011), while others have considered it quite harmless (FOSTER et al., 2008; ZINTL et al., 2014). Highly intense infections can cause damage in the mucosa and submucosa of the forestomachs and duodenum (FUERTES et al., 2015). Also reported are age-associated variations in the prevalence of adult flukes, with higher values found in adult 
animals than in young ones (GONZÁLEZ-WARLETA et al., 2013; SANCHÍS et al., 2013).

An increase of the prevalence of paramphistomids has been reported in several regions in Europe (Great Britain, Ireland, Belgium), and South America (Argentina) (MALRAIT et al., 2015; SANABRIA \& ROMERO, 2008), as well as a high seroprevalence (29\%) has been reported in Uruguay (SANCHÍS et al., 2013), which underline the importance of studying this group of parasite in new localities. Given that their life cycles are very similar to Fasciola hepatica, particularly in the free-living stages and snail-parasitizing stage, it is expected that both parasites have a similar distribution. However, despite the high frequency of $F$. hepatica in central Chile (MORALES et al., 2000), there are no published findings of paramphistomid trematodes in this country, except for an imported bull that was diagnosed shortly after its arrival (GONZÁLEZ \& PLAZA, 1966).

Considering the above, in this study, we searched for the presence of this parasite in the Chilean administrative regions of Maule, Nuble and Biobío, and in the southern Maule region, located between $35^{\circ} 25^{\prime} 6.95^{\prime \prime} \mathrm{S}$ and $38^{\circ} 29^{\prime} 38.14^{\prime \prime} \mathrm{S}$. This is a zone of central Chile where $F$. hepatica is frequently found. These regions have a transitional climate that falls somewhere between the classifications of warm Mediterranean and wet temperate. This territory includes two mountain ranges that run north-south: Los Andes (which separates the region from Argentina) and La Costa (which is west of Los Andes), and two flat lowlands: the Central Valley (between the mountain ranges) and the coastal plain (a narrow strip of land between the La Costa range and the Pacific Ocean). Given that cattle (Bos taurus taurus) constitute a species that can present higher prevalence rates of paramphistomids than other domestic ruminants (e.g. JONES et al., 2017; PLOEGER et al., 2017), and with good traceability in Chile, we chose this species to identify the origin of inspected animals in this study. The area studied harbors around $12 \%$ of the total cattle population in Chile, comprising about 460,000 animals (ODEPA, 2016). There is a greater likelihood of the presence of stagnant water, which favors the abundance of the intermediate host (snails) in the Central Valley and coastal plain when compared with the mountain ranges, therefore, we expected a higher prevalence of paramphistomids in districts located in the Central Valley and coastal plain rather than in districts with more mountainous terrain. The identifications of paramphistomids can be based on morphological attributes, but misidentifications have been reported (SANABRIA et al., 2009). On the other hand, the internal transcriber spacer 2 (ITS-2) fragment has been used for the identification of the paramphistomid species previously, showing that is a good marker for this purpose (SANABRIA et al., 2011).

Thus, this research aimed to determine the presence of paramphistomids in beef cattle slaughtered in a slaughterhouse of the Nuble Region of Chile, to identify the flukes and to analyze the frequency of these parasites in the Maule, Nuble, and Biobío regions.

\section{Materials and Methods}

\section{Sampling}

Between October of 2016 and April of 2017, 494 B. taurus taurus (sample size calculated following Vallejo et al. (2013), with an expected proportion of $50 \%$, an accepted error $<5 \%$, and a confidence level of 95\%) slaughtered in the Nuble Region were examined for flukes in the forestomachs. The details related to the origins of the animals are documented in Table 1. The animals included in the study correspond to all animals slaughtered in

Table 1. Frequency of presentation of Calicophoron microbothrioides in forestomachs of cattle by province and district in the Maule, Nuble and Biobío regions of Chile. October of 2016 - April of 2017. The codes added to the district name are that used in Figure 1.

\begin{tabular}{|c|c|c|c|c|}
\hline Province & District/Code & $\begin{array}{c}\text { Examined } \\
\text { Animals }\end{array}$ & $\begin{array}{c}\text { Frequency of presentation [\%] } \\
(95 \%, \text { confidence interval })\end{array}$ & $\begin{array}{c}\text { Mountain or flat lowlands } \\
\text { district }\end{array}$ \\
\hline Cauquenes & Cauquenes/1 & 1 & $100(5-100)$ & Mountain \\
\hline Linares & Linares/2 & 3 & $66.67(13.32-100)$ & Mountain \\
\hline \multirow[t]{4}{*}{ Punilla } & Niquén/3 & 21 & $28.57(9.25-47.89)$ & Lowland \\
\hline & San Carlos/4 & 178 & $11.80(7.06-19.54)$ & Lowland \\
\hline & San Nicolás/5 & 26 & $3.85(0.0-11.24)$ & Lowland \\
\hline & Coihueco/6 & 24 & $25(7.68-42.32)$ & Mountain \\
\hline \multirow[t]{5}{*}{ Diguillín } & Chillan/7 & 7 & $0(0-34.8)$ & Lowland \\
\hline & Chillan Viejo/8 & 13 & $30.77(5.68-55.86)$ & Lowland \\
\hline & Pinto/9 & 7 & $0(0-34.8)$ & Mountain \\
\hline & Bulnes/10 & 73 & $4.11(0.0-8.66)$ & Lowland \\
\hline & San Ignacio/11-El Carmen/12 & 10 & $0(0-25.9)$ & Mountain \\
\hline \multirow[t]{3}{*}{ Itata } & Quirihue/13 & 12 & $16.67(9.25-47.89)$ & Mountain \\
\hline & Ninhue/14-Coelemu/15 & 7 & $14.29(0-40.21)$ & Mountain \\
\hline & Portezuelo/16-Quillón/17 & 17 & $11.76(0-27.08)$ & Lowland \\
\hline Concepción & San Pedro de la Paz/18 & 2 & $0(0-77.64)$ & Lowland \\
\hline Arauco & Arauco/19 & 3 & $0(0-63.16)$ & Lowland \\
\hline \multirow[t]{4}{*}{ Biobío } & Cabrero/20 & 4 & $0(0-52.71)$ & Lowland \\
\hline & Los Ángeles/21 & 59 & $6.78(0.36-13.19)$ & Lowland \\
\hline & Mulchén/22-Santa Bárbara/23-Tucapel/24 & 27 & $11.11(0-22.97)$ & Mountain \\
\hline & Total & 494 & $11.34(8.54-14.13)$ & \\
\hline
\end{tabular}


each day of sampling, regardless of their origin, in such a way that the number of animals from each district was not previously determined.

\section{Flukes identification}

Flukes were fixed and conserved in $70 \%$ ethanol in $2 \mathrm{~mL}$ vials immediately after collecting in the slaughterhouse, and they were then identified morphologically and molecularly. For the morphological identification, three worms from San Carlos and one from each district with infected animals, total 15 worms, were stained with hydrochloric carmine and summited to increasing concentrations of ethanol until 100\%, then they were cleared in methyl salicylate, immersed in xylol and finally mounted in Permount ${ }^{\circledR}$. The identification was performed following Eduardo (1982; 1983) and Jones (2005). For the histological study, worms were fixed in $10 \%$ neutral formalin for $48 \mathrm{~h}$ at room temperature, processed routinely, and embedded in paraffin; 3- $\mu \mathrm{m}$ serial sections were stained with hematoxylin and eosin. The ranges (mean \pm standard deviation) of measures are given in results. For the molecular identification, a fragment of the internal transcriber spacer - 2 (ITS-2) region of the DNA was amplified and a phylogenetic analysis was performed in two worms from San Carlos and one from each district with infected animals, total 14 worms. These 14 Chilean DNA samples were genetically identical among them (null variability) and agreed with the morphological identification (see results), hence we did not include more samples for the analysis. DNA was extracted using the DNA Blood and Tissue Extraction Kit (Qiagen ${ }^{\circledR}$, Hilden, Germany) following the manufacturer' instructions. Polymerase chain reaction (PCR) was performed following the method of Sanabria et al. (2011). PCR products were summited to electrophoresis in $1.2 \%$ agarose gel, DNA was extracted from the gel with E.Z.N.A ${ }^{\circledR}$ Gel Extraction Kit, sequenced at Austral-Omics (ABI 3500 Genetic Analyzer, Applied Biosystems, capillary analyzer system, Universidad Austral de Chile) and the sequences were included in GenBank with accession numbers MK683484-MK683497. For a first molecular identification, the sequences were analyzed by means of the Basic Local Alignment Search Tool (BLAST) in GenBank.

\section{Phylogenetic and statistical analysis}

For phylogenetic analyses only two of the 14 Chilean isolates were used given the $100 \%$ identity among them. The same criterion was used for including in the analysis other sequences with $100 \%$ identity when they come from the same study. Sequences were aligned with ClustalW method and a pairwise distance matrix was constructed with Mega 7 Software. Phylogenetic analysis was performed by Bayesian inference. For the latter, the best model and the parameters for tree construction were obtained by means of j Model Test 2.1.10 software, where AIC criteria were selected, and the phylogenetic tree was constructed with Mr. Bayes 3.2.6. This analysis was subjected to 2,000,000 bootstraps to test the reliability of individual branches within the generated tree. Sequences of most Paramphistomidae species were included in the analysis. These were obtained from GenBank, with preference for those that had a publication with a PubMed Identifier (PMID) code included in the GenBank sequence record. GenBank codes of the included sequences are shown in the identification of the sequences in the phylogenetic tree in results. Some sequences included in the analysis did not have a linked publication, and they were identified with a hyphen between the GenBank code and the species name in the tree. $F$. hepatica and F. gigantica (different family) were used as the external group for this analysis.

Fisher's exact test (significance level $=0.05$ ) was used to compare the frequencies of parasite presentation between districts belonging to the Central Valley and coastal plain and those that extend into the Los Andes and La Costa mountain ranges (see Table 1 and Figure 1 for the details of districts belonging to each category), as well as between adult animals ( 2 or more years old) and young animals (less than 2 years old). 95\% confidence intervals (CI) of the frequencies of presentation were estimated with the online Working in Epidemiology platform (http://www.winepi.net/sp/ index.htm), and they are reported in Table 1.

The Ethics Committee of the Veterinary Sciences Faculty at the Universidad de Concepción approved and certified this study.

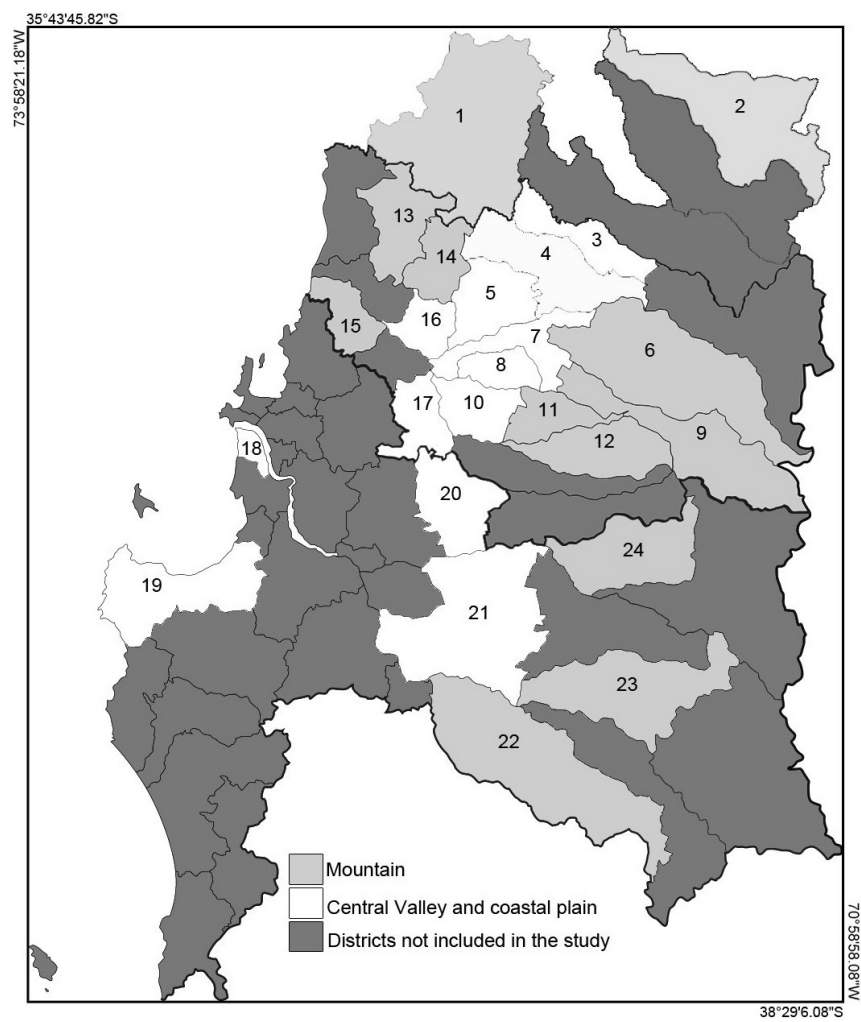

Figure 1. Map of the southern part of the Maule Region, Nuble Region and Biobío Region. The names of the districts included in this study are detailed in the Table 1 and correspond to each number (code) included in this map. 


\section{Results}

\section{Statistical reports}

A total of 56 of 494 forestomachs (11.3\%) were found to be colonized with flukes. When considering districts with more than 10 examined animals, those with the highest frequencies of fluke presentation were Chillán Viejo (30.8\%, n=13), Niquén (28.6\%, $\mathrm{n}=21)$, and Coihueco $(25 \%, \mathrm{n}=24$; Table 1$)$.

Only 384 animals were recorded as adult or young animal. The frequency of infection was significantly higher in adult cattle than in young cattle $(35.8 \%, \mathrm{n}=53$ and $5.4 \%, \mathrm{n}=331$, respectively; $p<0.01)$. The frequencies with which the animals were infected in the Central Valley and coastal plain districts
$(10.2 \%, \mathrm{n}=403$ animals) were not significantly different from those districts that extended into to the Los Andes and La Costa mountain ranges $(16.5 \%, \mathrm{n}=91 ; p=0.1)$.

\section{Morphological identification}

The specimens were characterized by a conical and ventrally curved body that was $5.88-6.68 \mathrm{~mm}(6.28 \pm 0.57 \mathrm{~mm})$ in length, with a subterminal oral aperture (Figure 2). The pharynx, measuring $687.8-748.5 \mu \mathrm{m}(718.15 \pm 42.92 \mu \mathrm{m})$ by $597.8-686.8 \mu \mathrm{m}$ $(642.3 \pm 62.93 \mu \mathrm{m})$ was a calicophoron-type with small papillae on its surface at the sagittal section. The esophagus was characterized by the presence of an esophageal bulb, $735.4 \mu \mathrm{m}$ length. The caeca were coiled, reaching the acetabulum. The genital pore opening
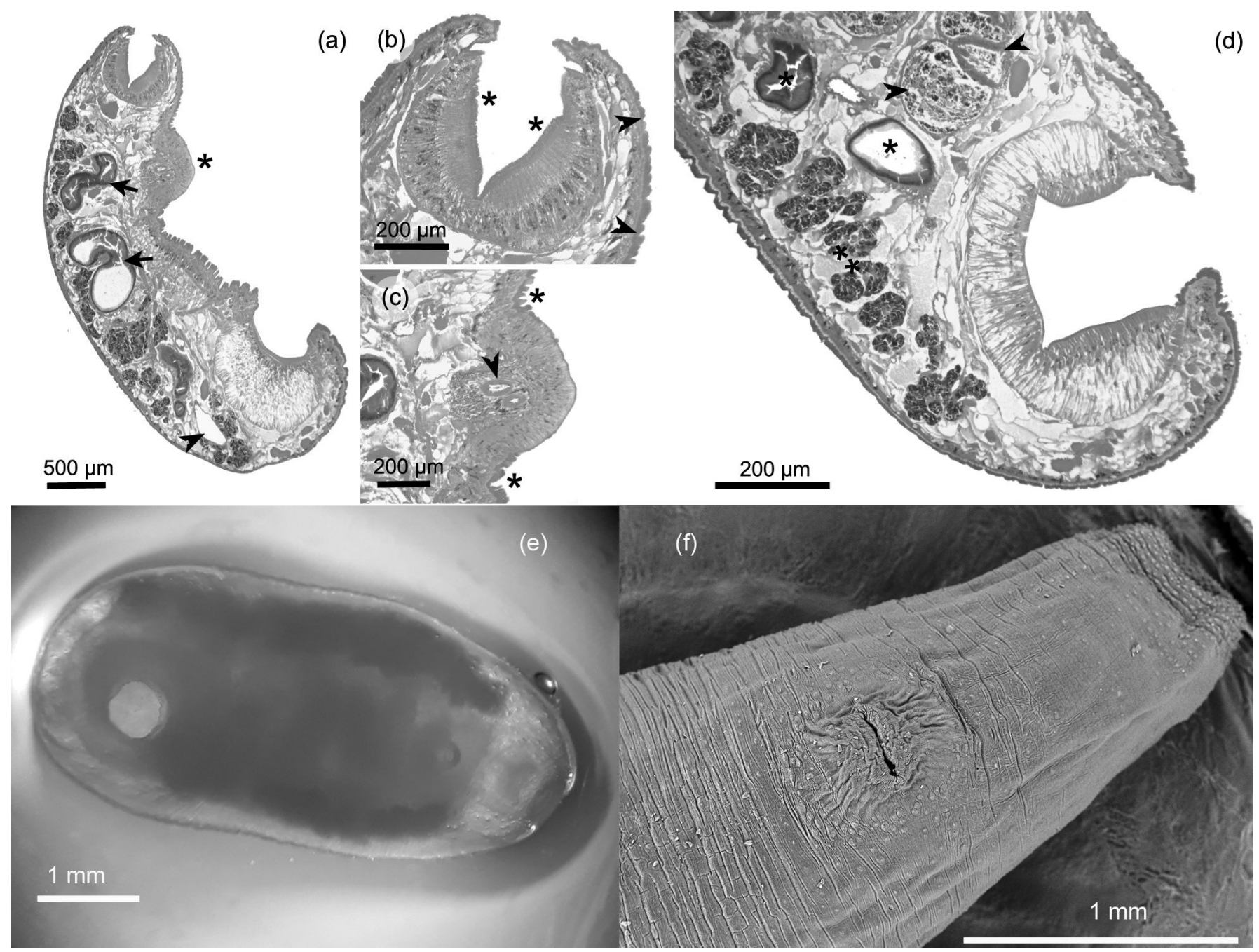

Figure 2. (a-d) In toto sagittal section of fluke Calicophoron microbothrioides. (a) Note pharynx located in first third of body and medium-size acetabulum in caudal third of body. There is also a prominent swelling over ventral surface around genital pore area, typical for this species $\left.{ }^{*}\right)$, sections of uterine coils (arrows) and excretory vesicle in dorsal part of body, with the latter located over acetabulum (arrow head). (b) Calicophoron-type pharynx covered with small papillae over its surface $\left(^{*}\right)$ and papillae increasing in size from cranial to caudal direction over tegument (arrow heads). (c) Swelling in ventral surface of body; note terminal genitalium which will open to the genital pore (arrow head), there are notorious papillae over tegument $\left(^{*}\right)$. (d) Sub-median section of caudal third of body; note pisum-type acetabulum being surrounded by lobulated testis (arrow heads), coils of uterus in the dorsal part of body (asterisks) and vitellaria ( ${ }^{* *}$ ). (e) External view of C. microbothrioides in a stereomicroscope with oblique light. (f) Scanning electron microscope view of the anterior end of a C. microbothrioides, with a zoom on the genital pore and surrounding papillae. 
was at the ventral surface, located caudal to the caecal bifurcation and surrounded by a prominent semicircular swelling at the sagittal section. Vitellaria were organized in two lateral fields, beginning caudal to the oral sucker and reaching the anterior border of the acetabulum, not converging at either the anterior or posterior end. The testes were located at the midline of the body and were tandem and deeply lobulated; further, the anterior testis was $0.73-1.15 \mathrm{~mm}(0.94 \pm 0.30 \mathrm{~mm})$ in length and the posterior testis was $0.77-1.17 \mathrm{~mm}(0.97 \pm 0.28 \mathrm{~mm})$ in length. The ovary was subspherical and measured 330.4-376.1 $\mu \mathrm{m}(353.25 \pm 32.31 \mu \mathrm{m})$ by 312.4-327.4 $\mu \mathrm{m}(319.9 \pm 10.61 \mu \mathrm{m})$, and Mehlis' gland was close to it. Both were submedian and post-testicular. The excretory vesicle was dorsal to the acetabulum, ovary, and Mehlis' gland at the sagittal section. The uterus was filled with translucent oval eggs measuring $115.80-131.20 \mu \mathrm{m}(122.79 \pm 4.87 \mu \mathrm{m})$ by $56.10-66.30 \mu \mathrm{m}(61.84 \pm 3.06 \mu \mathrm{m})$. A medium-sized subterminal acetabulum, $1.23-1.29 \mathrm{~mm}(1.26 \pm 0.04 \mathrm{~mm})$ in diameter, was located at the posterior third of the body, and was pisum-type at the sagittal section. The tegument was covered with small papillae around the oral aperture and genital pore, and demonstrated an increased size from the oral aperture to the genital pore, being dome-shaped around the latter.

\section{Molecular analyses}

A 460 bp-length fragment of DNA was amplified in the 14 samples. The BLAST analysis output shared $100 \%$ identity with both Paramphistomum cervi Linnaeus, 1758 and Calicophoron microbothrioides Price \& McIntosh, 1944 (Digenea: Paramphistomidae), as well as the distance between those species where 0.000 (Table 2). As expected, after BLAST analysis, the phylogenetic tree grouped Chilean sequences with $P$. cervi and C. microbothirioides (Figure 3). The tree also showed sequences of the same species grouped together but did not group together species of the same genus.

\section{Discussion}

This is the first study to examine the frequency of paramphistomids in Chile. We expected a higher frequency in districts restricted to the lowlands (Central Valley and coastal plain) than those that included mountainous terrain; however, there were no significant differences. This could be due to the fact that those districts containing mountains also contained flat terrain in both the low- and highlands; these were the territories used for beef cattle

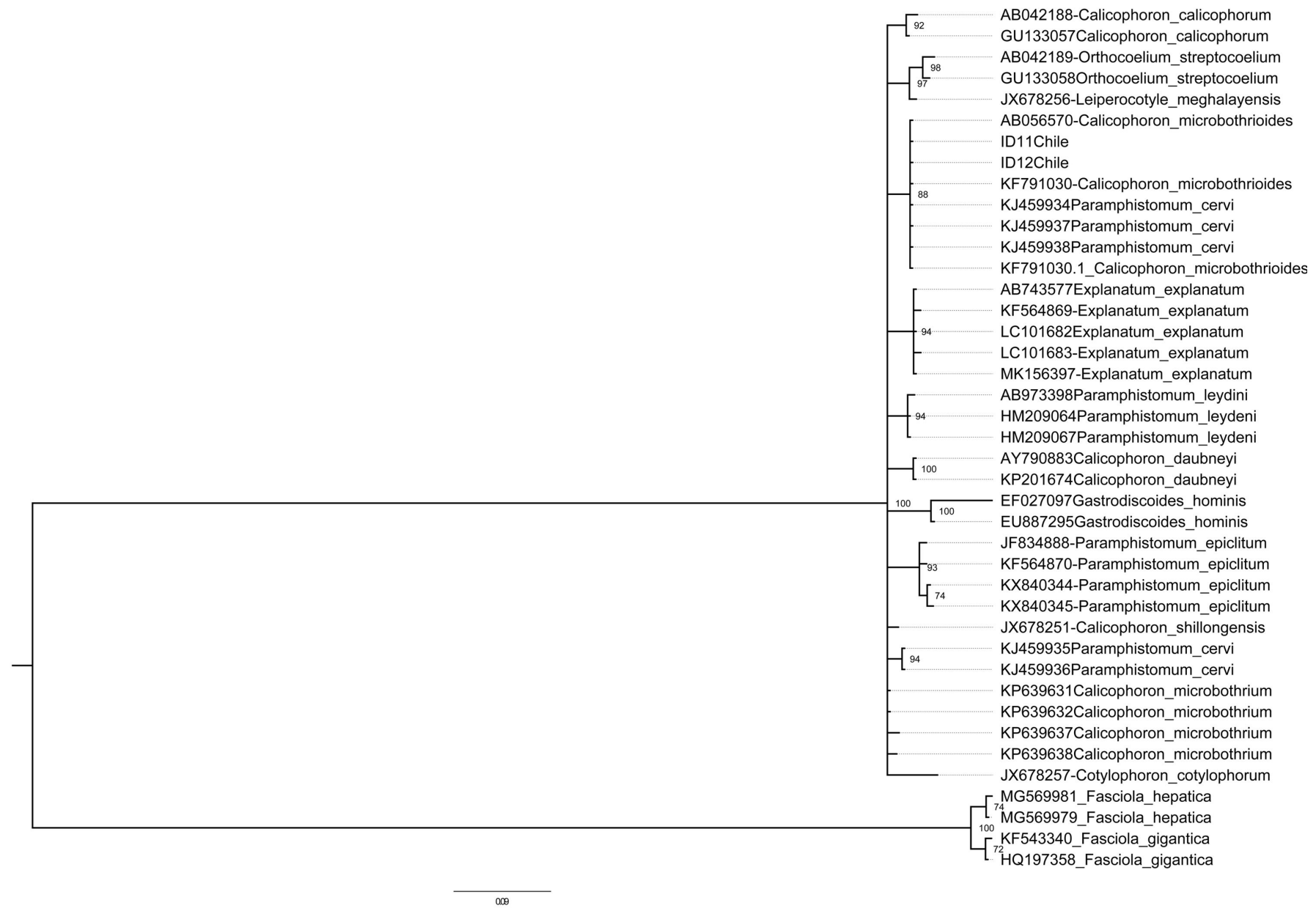

Figure 3. Bayesian inference tree based on 460 nucleotides of the Internal Transcribed Spacer 2 segment of the ribosomal DNA, reconstructed under TPM3uf+G substitution model. Posterior probability values are indicated to each node. Fasciola spp. were used as outgroup control. 


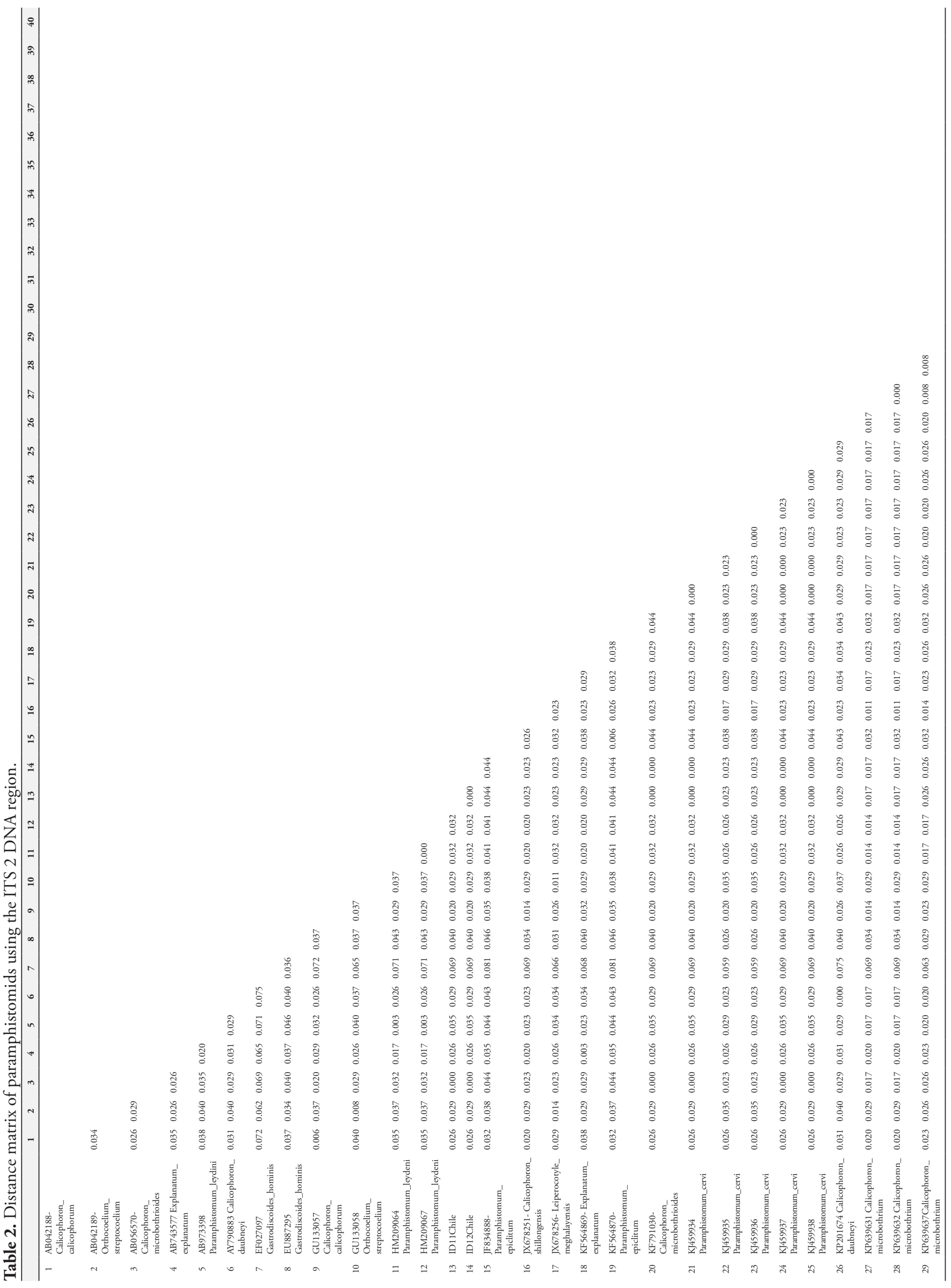




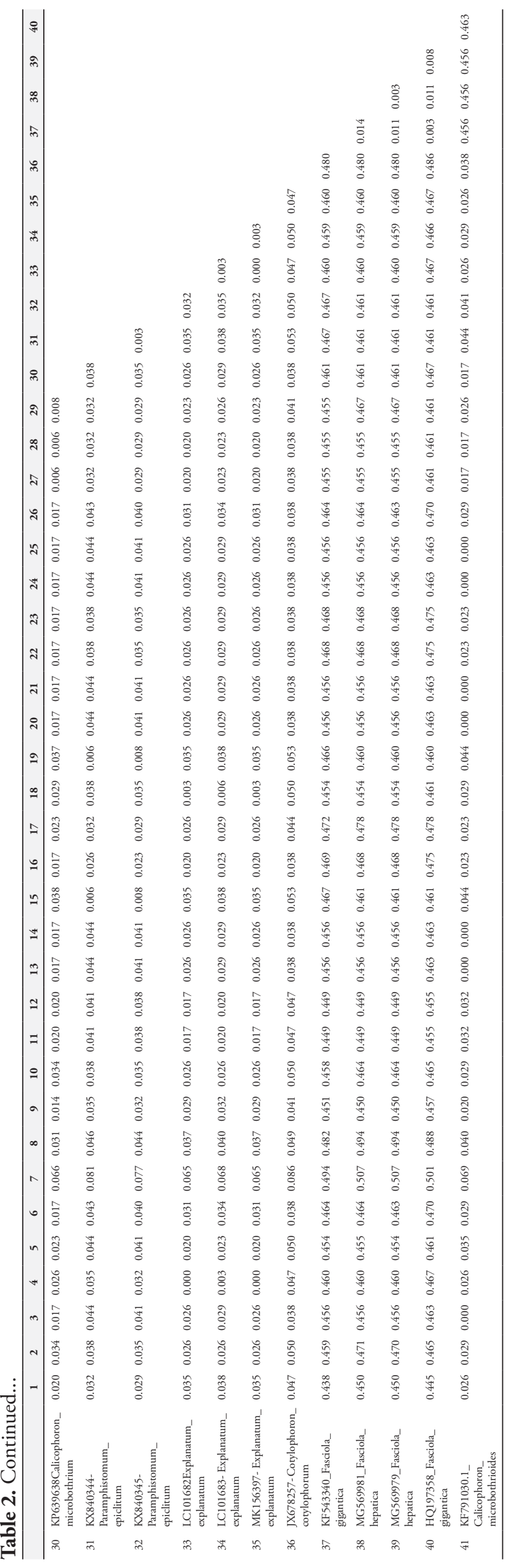


livestock. Conversely, the most sloping lands were used for sheep or goat grazing. Thus, the availability of stagnant water for the cycle of flukes was also present in those districts.

The higher frequency of parasites in the adult category were in agreement with the findings of previous reports (GONZÁLEZ-WARLETA et al., 2013; SANCHÍS et al., 2013), and can be explained by longer exposure to the infections, to the amount of time the parasite takes to arrive to the forestomach and the fluke's longevity. Given the protocols followed at the slaughterhouse, and the practical difficulties associated with them, it was not possible to analyze the other segments of the digestive tract when searching for the presence of larvae. Thus, our results are narrowed to adult worms.

Taxonomically, our samples can be distinguished from the Paramphistomum Fischoeder, 1901 genus, as the testes are slightly lobulated or smooth in Paramphistomum, which contrasts with our samples, which were deeply lobulated. Paramphistomum also lacks an esophageal bulb, a calicophoron-type pharynx, and a pisum-type acetabulum (EDUARDO, 1982, 1983; JONES, 2005). Paramphistomum also has a liorchis-type pharynx and paramphistomum-type acetabulum

The present species can be distinctive from other ruminal fluke genus, Cotylophoron Stiles \& Goldberger, 1910, because Cotylophoron has a true genital sucker and a cotylophoron-type acetabulum. Regarding species of Calicophoron, flukes herein reported can be differentiated from: C. calicophorum because the latter species has a tegument devoid of papillae around genital pore; C. bothriophoron because it has a deeply depression around genital pore and lacks of esophageal bulb; $C$. microbothrium because it has a paramphistomum-type acetabulum and a non-prominent swelling around genital pore, and lacks of esophageal bulb; C. papillosum because it has a calicophoron-type acetabulum and tegumental papillae only around oral opening and wall of genital atrium, C. papillosum also lacks of esophageal bulb; C. papilligerum because its caeca reach about middle section of acetabulum and is devoid of tegumental papillae; C. raja because it has smaller papillae around genital pore than oral opening and its esophagus lacks of bulb; C. clavula because it has a paramphistomum-type acetabulum and a reduced number of smaller papillae around genital pore compared to oral opening, and lacks of esophageal bulb; $C$. sukari because it has a non-prominent swelling around genital pore, calicophoron-type acetabulum, oesophagus with no bulb and vitellaria confluent in their anterior limits; C. phillerouxi because it has papillae only on surface around oral opening, non-prominent swelling around genital pore, paramphistomum-type acetabulum, and lacks of esophageal bulb; $C$. daubneyi because it has papillae around oral opening and no papillae around genital pore, paramphistomum-type acetabulum, and lacks of esophageal bulb; and, finally, from C. sukumum because it has a small swelling around genital pore devoid of papillae and lacks of esophageal bulb (EDUARDO, 1982, 1983; JONES, 2005)

The phylogenetic tree allowed us to verify that the ITS-2 segment was a good marker for the species (isolates of the same species tend to be grouped together), but not for genera (species of the same genus were not grouped together in the same branch). In a closer view, as mentioned, our sequences were $100 \%$ identical to three isolates of $P$. cervi and four isolates of $C$. microbothrioides available in GenBank.

Therefore, following morphological analysis, and in concert with the molecular analysis, the flukes were classified as $C$. microbothrioides.

We conducted an additional exploration to determine additional taxonomical commentaries in Zheng et al. (2014), the study that published on P. cervi and whose sequences were identical to those in the present study. Upon further exploration, we did not find information about their identification. The authors also published P. cervi sequences that diverged from our samples. The supposition that observed distances are real distances means that a lack of mutations in the studied segment may explain the presence of two genera in the same clade. However, the real distance could be longer than the observed distance, in such a way that divergent mutations could take place first, and with convergent ones taking place later; thus, identical sequences are observed. In addition, misclassifications of paramphistomids have been reported previously in the literature (SANABRIA et al., 2009). All above underline the need of including molecular and morphological approach together in order to have a more precise classification of these parasites.

There were no published articles (with an associated PMID code) for the sequence of $C$. microbothrioides in the record of this sequence. Therefore, the morphological analysis allowed us to finally determine the species.

It is difficult to establish the economic importance of C. microbothrioides since studies in this species are scarce. Other species of Calicophoron as $C$. daubneyi are more studied. For instance, animals with single infection of adult $C$. daubneyi showed lower cold carcass weight and lower fat class than helminth-free animals (BELLET et al., 2016). The higher abundance of $C$. daubneyi has been also associated with higher frequency of thin or watery fecal consistence and lower frequency of normal feces (MALRAIT et al., 2015). On the other hand, the intensity of infection with another Calicophoron, C. microbothrium, was associated with severity of lesions in the abomasal folds, comprising edema, as well as in the duodenum, comprising duodenal thickening, corrugation, hyperemia, petechiation, ulceration, callous atrophy, hyperplasia of Brunner's glands and Peyer's patches, and infiltration of eosinophils, mast cells, basophils and lymphocytes in the lamina propria (MAVENYENGWA et al., 2005). Although there is no knowledge about the economic impact of $C$. microbothrioides, the mentioned damage of other Calicophoron species suggest that it is important to develop control strategies. The lack of knowledge also underlines the need of developing new research about the pathology and the production and economic loses because C. microbothrioides in Chile.

This research represents the first report of $C$. microbothrioides in Chile. As mentioned, only one case of paramphistomid infection was reported in Chile previously and was documented in a bull that was diagnosed shortly after the arrival. The species Cotylophoron cotylophorum was identified in that case (GONZÁLEZ \& PLAZA, 1966). It is interesting that in Chile, to the best of authors' knowledge, there is no report of eggs belonging to Paramphistomidae. It is possible that a misidentification could have happened, confusing them with $F$. hepatica. Worldwide reports of $C$. microbothrioides are scarce. For instance, this species was previously reported in Malaysia (LEE et al., 1987), the United 
States (HERD \& HULL, 1981; ZUKOWSKI et al., 1993), and Canada (BOUVRY \& RAU, 1984). The literature also mentions the presence of this species in Europe, encompassing Bulgaria, the Czech Republic, and Hungary (FAUNA-EUROPAEA, 2019). There are no reports of $C$. microbothrioides in published papers in South America; the only precedents correspond to two records of this species from Peru in GenBank.

Future studies must be focused on exploring the economic importance of this species, and on determining the pathological damage to the host, since these consequences seem to differ in various regions (FOSTER et al., 2008; DORNY et al., 2011; ZINTL et al., 2014) and in the different paramphistomid species (See literature reviewed in ZINTL et al., 2014). An important intermediate host for ruminal flukes ( $C$. daubneyi) in Europa, Galba truncatula (AUGOT et al., 1996; DREYFUSS et al., 2014), is also present in Chile (ARTIGAS et al., 2011), and one of the localities reported to harbor this snail, Chillán, is in the region where this study was performed, in such a way that $G$. truncatula can be an important intermediate host for this fluke. Future studies must also focus on the cycle of this parasite species, particularly to confirm $G$. truncatula as an intermediate host and to search for other possible intermediate hosts. A deeper knowledge of the intermediate host could guide control strategies.

\section{Acknowledgements}

Authors thank Cristian Álvarez Rojas for helpful suggestions for the improvement of this work. Authors thank Eileen Smith for editorial support. This study was funded by the Comisión Nacional de Investigación Científica y Tecnológica (Grant FONDECYT 11170294; FONDEQUIP EQM170124)

\section{References}

Ali Q, Rashid I, Shabbir MZ, Akbar H, Shahzad K, Ashraf K, et al. First genetic evidence for the presence of the rumen fluke Paramphistomum epiclitum in Pakistan. Parasitol Int 2018; 67(5): 533-537. http://dx.doi. org/10.1016/j.parint.2018.05.005. PMid:29758277.

Artigas P, Bargues MD, Mera y Sierra RL, Agramunt VH, Mas-Coma S. Characterisation of fascioliasis lymnaeid intermediate hosts from Chile by DNA sequencing, with emphasis on Lymnaea viator and Galba truncatula. Acta Trop 2011; 120(3): 245-257. http://dx.doi.org/10.1016/j. actatropica.2011.09.002. PMid:21933653.

Augot D, Abrous M, Rondelaud D, Dreyfuss G. Paramphistomum daubneyi and Fasciola hepatica: the redial burden and cercarial shedding in Lymnaea truncatula subjected to successive unimiracidial cross-exposures. Parasitol Res 1996; 82(7): 623-627. http://dx.doi.org/10.1007/s004360050175. PMid:8875570.

Bellet C, Green MJ, Vickers M, Forbes A, Berry E, Kaler J. Ostertagia spp., rumen fluke and liver fluke single- and poly-infections in cattle: an abattoir study of prevalence and production impacts in England and Wales. Prev Vet Med 2016; 132: 98-106. http://dx.doi.org/10.1016/j. prevetmed.2016.08.010. PMid:27664452.

Bouvry M, Rau ME. Paramphistomum spp. in dairy cattle in Québec. Can Vet J 1984; 25(9): 353-356. PMid:17422453.
Dorny P, Stoliaroff V, Charlier J, Meas S, Sorn S, Chea B, et al. Infections with gastrointestinal nematodes, Fasciola and Paramphistomum in cattle in Cambodia and their association with morbidity parameters. Vet Parasitol 2011; 175(3-4): 293-299. http://dx.doi.org/10.1016/j.vetpar.2010.10.023. PMid:21071148.

Dreyfuss G, Vignoles P, Rondelaud D. Fasciola hepatica and Paramphistomum daubneyi: decrease in prevalence of natural infection in habitats colonized by Galba truncatula and Lymnaea glabra. Rev Med Vet 2014; 165(5-6): 160-166.

Eduardo SL. The taxonomy of the family Paramphistomidae Fischoeder, 1901 with special reference to the morphology of species occurring in ruminants. I. General considerations. Syst Parasitol 1982; 4(1): 7-57. http://dx.doi.org/10.1007/BF00012228.

Eduardo SL. The taxonomy of the family Paramphistomidae Fischoeder, 1901 with special reference to the morphology of species occurring in ruminants. III. Revision of the genus Calicophoron Näsmark, 1937. Syst Parasitol 1983; 5: 25. http://dx.doi.org/10.1007/BF00010983. PMid:27432375.

Fauna Europaea. Calicophoron microbothrioides (Price \& McIntosh, 1949) [online]. 2019 [cited 2019 Apr 10]. Available from: https://fauna-eu. org/cdm_dataportal/taxon/2a39fd1f-92c0-4ba8-85be-48a4b4691db4

Foster AP, Otter A, O’Sullivan T, Cranwell MP, Twomey DF, Millar MF, et al. Rumen fluke (paramphistomosis) in British cattle. Vet Rec 2008; 162(16): 528. http://dx.doi.org/10.1136/vr.162.16.528-a. PMid:18424857.

Fuertes M, Pérez V, Benavides J, González-Lanza MC, Mezo M, GonzálezWarleta M, et al. Pathological changes in cattle naturally infected by Calicophoron daubneyi adult flukes. Vet Parasitol 2015; 209(3-4): 188196. http://dx.doi.org/10.1016/j.vetpar.2015.02.034. PMid:25801360.

González H, Plaza J. Hallazgo de trematodes de la familia Paramphistomidae en bovinos importados desde Australia. Bol Chil Parasitol 1966; 21(1): 19-21. PMid:5930180.

González-Warleta M, Lladosa S, Castro-Hermida JA, Martínez-Ibeas AM, Conesa D, Muñoz F, et al. Bovine paramphistomosis in Galicia (Spain): Prevalence, intensity, aetiology and geospatial distribution of the infection. Vet Parasitol 2013; 191(3-4): 252-263. http://dx.doi. org/10.1016/j.vetpar.2012.09.006. PMid:23022489.

Herd RP, Hull BL. Paramphistomum microbothrioides in American bison and domestic beef cattle. J Am Vet Med Assoc 1981; 179(10): 1019-1020. PMid:7341559.

Huson KM, Oliver NAM, Robinson MW. Paramphistomosis of ruminants: an emerging parasitic disease in Europe. Trends Parasitol 2017; 33(11): 836-844. http://dx.doi.org/10.1016/j.pt.2017.07.002. PMid:28754416.

Jones A. Family Paramphistomidae Fischoeder, 1901. In: Jones A, Bray RA, Gibson DI. Keys to the Trematoda. vol. 2. London: CABI Publishing; 2005. p. 229-246. http://dx.doi.org/10.1079/9780851995878.0229.

Jones RA, Brophy PM, Mitchell ES, Williams HW. Rumen fluke (Calicophoron daubneyi) on Welsh farms: prevalence, risk factors and observations on co-infection with Fasciola hepatica. Parasitology 2017; 144(2): 237-247. http://dx.doi.org/10.1017/S0031182016001797. PMid:28145217.

Lee CC, Sheikh-Omar AR, Jones A. Calicophoron microbothrioides (Price and McIntosh, 1944) (Paramphistomidae: Paramphistominae) in Malaysian sambar deer (Cervus unicolor). NZ Vet J 1987; 35(11): 190-191. http:// dx.doi.org/10.1080/00480169./1987.35442. PMid:16031343.

Malrait K, Verschave S, Skuce P, Van Loo H, Vercruysse J, Charlier J. Novel insights into the pathogenic importance, diagnosis and treatment 
of the rumen fluke (Calicophoron daubneyi) in cattle. Vet Parasitol 2015; 207(1-2): 134-139. http://dx.doi.org/10.1016/j.vetpar.2014.10.033. PMid:25466618.

Mavenyengwa M, Mukaratirwa S, Obwolo M, Monrad J. A macro- and light microscopical study of the pathology of Calicophoron microbothrium infection in experimentally infected cattle. Onderstepoort J Vet Res 2005; 72(4): 321-332. http://dx.doi.org/10.4102/ojvr.v72i4.189. PMid:16562736.

Morales MA, Luengo J, Vásquez J. Distribución y tendencia de la fasciolosis en ganado de abasto en Chile, 1989-1995. Parasitol Día 2000; 24(3-4): 115-118. http://dx.doi.org/10.4067/S0716-07202000000300009.

Naranjo-Lucena A, Munita Corbalán MP, Martínez-Ibeas AM, McGrath G, Murray G, Casey M, et al. Spatial patterns of Fasciola hepatica and Calicophoron daubneyi infections in ruminants in Ireland and modelling of $C$. daubneyi infection. Parasit Vectors 2018; 11(1): 531. http://dx.doi. org/10.1186/s13071-018-3114-z. PMid:30268155.

O'Connor L, Choudhury B, Ali S, Bull K, Morgan E. A survey of gastrointestinal parasites of wild and orphan greater one-horned rhino (Rhinoceros unicornis) in Kaziranga National Park, Assam, India. J Zoo Wildl Med 2018; 49(4): 1051-1053. http://dx.doi.org/10.1638/20180051.1. PMid:30592923.

Odepa. Existencia de ganado bovino en explotaciones con rebaños de 10 cabezas y más, según regiones seleccionadas Años 2007,2013 y 2015 [online]. 2016 [cited 2019 Apr 10]. Available from: https://www.odepa.gob.cl/ wp-content/uploads/2016/06/ExistenciasBovinosOvinosCaprinos.xls

Ploeger HW, Ankum L, Moll L, van Doorn DCK, Mitchell G, Skuce PJ, et al. Presence and species identity of rumen flukes in cattle and sheep in the Netherlands. Vet Parasitol 2017; 243: 42-46. http://dx.doi. org/10.1016/j.vetpar.2017.06.009. PMid:28807308.

Sanabria R, Moré G, Romero J. Molecular characterization of the ITS-2 fragment of Paramphistomum leydeni (Trematoda: paramphistomidae). Vet Parasitol 2011; 177(1-2): 182-185. http://dx.doi.org/10.1016/j. vetpar.2010.11.023. PMid:21145661.
Sanabria R, Romero J. Review and update of paramphistomosis. Helminthologia 2008; 45(2): 64-68. http://dx.doi.org/10.2478/s11687008-0012-5.

Sanabria REF, Martorelli SR, Romero JR. First report of Paramphistomum leydeni Näsmark, 1937 (Trematoda: Paramphistomidae) in Argentina, and re-examination of Cotylophoron cotylophorum sensu Racioppi et al. (1994). Helminthologia 2009; 46(4): 225-229. http://dx.doi.org/10.2478/ s11687-009-0042-7.

Sanchís J, Sánchez-Andrade R, Macchi MI, Piñeiro P, Suárez JL, Cazapal-Monteiro C, et al. Infection by Paramphistomidae trematodes in cattle from two agricultural regions in NW Uruguay and NW Spain. Vet Parasitol 2013; 191(1-2): 165-171. http://dx.doi.org/10.1016/j. vetpar.2012.07.028. PMid:22902261.

Vallejo A, Muniesa A, Ferreira C, Blas I. New method to estimate the sample size for calculation of a proportion assuming binomial distribution. Res Vet Sci 2013; 95(2): 405-409. http://dx.doi.org/10.1016/j.rvsc.2013.04.005. PMid:23623739.

Zheng X, Chang Q-C, Zhang Y, Tian S-Q, Lou Y, Duan H, et al. Characterization of the complete nuclear ribosomal DNA sequences of Paramphistomum cervi. ScientificWorldJournal 2014; 2014: 751907. http://dx.doi.org/10.1155/2014/751907. PMid:25140347.

Zintl A, Garcia-Campos A, Trudgett A, Chryssafidis AL, Talavera-Arce S, Fu Y, et al. Bovine paramphistomes in Ireland. Vet Parasitol 2014; 204(3-4): 199-208. http://dx.doi.org/10.1016/j.vetpar.2014.05.024. PMid:24907069.

Zukowski SH, Wilkerson GW, Malone JB Jr. Fasciolosis in cattle in Louisiana. II. Development of a system to use soil maps in a geographic information system to estimate disease risk on Louisiana coastal marsh rangeland. Vet Parasitol 1993; 47(1-2): 51-65. http://dx.doi. org/10.1016/0304-4017(93)90175-M. PMid:8493767. 